\title{
Study on Hydrographical Properties in the Surface Coastal Waters along the Gulf of Aden and Arabian Sea, Yemen
}

\author{
Ibrahim A. Al-Akhaly*1, Nabil A. Al-Shwafi ${ }^{1}$ and Mohummed A. Al-Safany ${ }^{2}$ \\ ${ }^{1}$ Faculty of Petroleum and Natural Resources, Sana'a University, Yemen \\ ${ }^{2}$ Faculty of Marine Science, King Abdulaziz University, Saudi Arabia
}

*Corresponding author: Ibrahim A. Al-Akhaly. Faculty of Petroleum and Natural

Resources, Sana'a University, Yemen; E-mail: Ibnalakhaly@hotmail.com

Received Date: June 12, 2020

Published Date: July 14, 2020

\begin{abstract}
The study of hydrographic properties of coastal environments is important, because the variations in the instantly influence on the floral and faunal production. Spatial distributions of hydrographic properties in the surface layer of the coastal waters along the Gulf of Aden and Arabian Sea, Yemen in August 2014 and January 2015 are presented in this study. Water samples were collected from 12 stations located between As suqayyah in the west and Hawf in the east. The hydrographical properties; air and water temperature, salinity, dissolved oxygen (DO), pH and total alkalinity of the coastal water of the Gulf of Aden and Arabian Sea of Yemen, were determined. In August 2014, the air temperature ranged between 22.00 and $26.30^{\circ} \mathrm{C}$ with mean value of $23.80 \pm 1.58 \mathrm{oC}$. Water temperature ranged from 23.70 to $28.10^{\circ} \mathrm{C}$ with mean value of $26.03 \pm 1.56^{\circ} \mathrm{C}$. The $\mathrm{pH}$ values ranged between 7.88 and 8.02 at different stations. The salinity showed not much variation among the sampling stations. DO values ranged between 4.10 and $4.65 \mathrm{mg} / \mathrm{l}$ with mean value of $4.42 \pm 0.19 \mathrm{mg} / \mathrm{l}$. The total alkalinity values ranged from 2.270 to $2.325 \mathrm{meq} / \mathrm{l}$ with mean value of $2.307 \pm 0.020$ meq/l, while the air temperature ranged between 23.00 and $26.30^{\circ} \mathrm{C}$ with mean value of $24.44 \pm 1.25^{\circ} \mathrm{C}$. Water temperature ranged from $25.20 \mathrm{oC}$ to $28.70^{\circ} \mathrm{C}$ with mean value of $26.65 \pm 1.11{ }^{\circ} \mathrm{C}$. The $\mathrm{pH}$ values ranged between 7.89 and 8.03 at different stations. The salinity showed not much variation among the sampling stations. DO values ranged between 4.78 and $5.50 \mathrm{mg} / \mathrm{l}$ with mean value of $5.05 \pm 0.25 \mathrm{mg} / \mathrm{l}$. The total alkalinity ranged from 2.234 to $2.359 \mathrm{meq} / \mathrm{l}$ with mean value of $2.301 \pm 0.031 \mathrm{meq} / \mathrm{l}$ in January 2015. The results obtained reflect the effect of the warm tropical zone of the Gulf of Aden and Arabian Sea of Yemen, irregular topography, local hydrographic condition and result of upwelling current. Statistical analysis like Pearson correlation matrix was performed to the data set to know the relationship among the studied properties. The quantitative analysis of hydrographical variability of the study region provides a baseline for assessing future changes.
\end{abstract}

\section{Introduction}

Coastal environments play a vital role in a nation's economy by virtue of their resources, productive habitats and rich biodiversity. They have been assuming greater importance, owing to their increasing human population, urbanization and accelerated developmental activities [1]. Coastal area is influenced by the interaction between land and sea. Important physical and chemical parameters influencing the aquatic environment are temperature, $\mathrm{pH}$, salinity, $\mathrm{DO}, \mathrm{CO}_{2}$, total suspended and dissolved solids, total alkalinity, acidity and heavy metal contaminants. These

parameters are the limiting factors for the survival of aquatic organisms [2]. Thus the nature and distribution of flora and fauna in an aquatic system are mainly controlled by the fluctuations in the hydrographical properties of the water body [3]. Generally marine environment is a complex system and mainly influenced by various physical, chemical and biological process. The open ocean is more stable compared to the near shore waters, where the interaction with the terrestrial zone is more effective in bringing about variations in different hydrographical properties. Hence a 
thorough knowledge of hydrography is indispensable to estimate the quality of the environment and its influence on biological fertility [4]. The water quality depends on both natural processes, such as precipitation erosion, weathering of crustal materials and anthropogenic processes like urbanization, industrialization, mining and agricultural activities [5]. The coastal hydrography is much complicated due to the dynamic nature of the ecosystem. The quality of water in any ecosystem provides significant information about the available resources for supporting life in that ecosystem. Good quality of water resources depends on a large number of hydrographical properties and biological characteristics. So, monitoring of these parameters is essential to identify the magnitude and source of any pollution load [6]. The hydrological study is very much essential to understand the relationship between its different trophic levels and food webs. The Gulf of Aden is a narrow, elongated, oceanic basin bordering the coastlines of southern Yemen and northern Somalia (Figure 1).

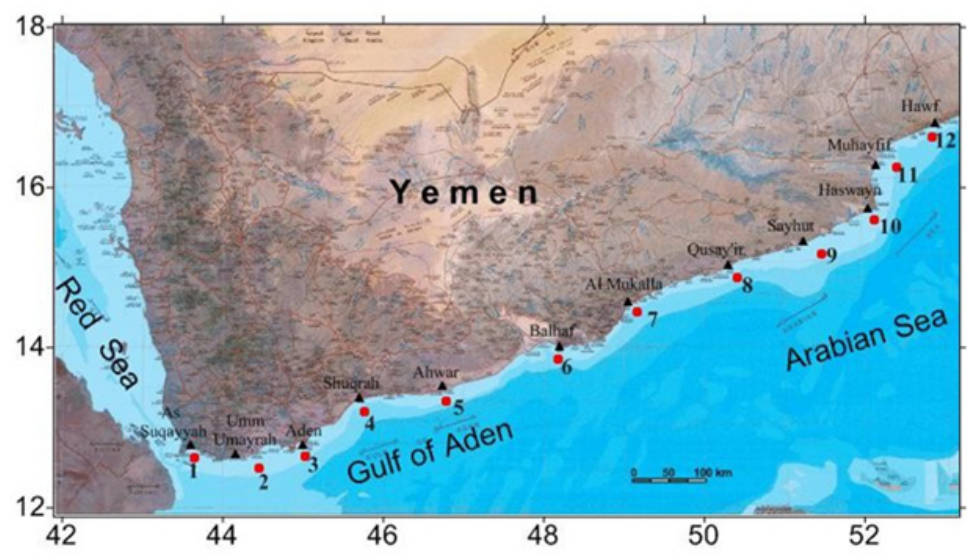

Figure 1: Map of Gulf of Aden and Arabian Sea showing the sampling stations.

For this reason, the physical oceanography of the area has been carefully studied and the main physical processes that occur in the gulf are well understood. Water exchange between the Red Sea and the Gulf of Aden is influenced by the seasonal reversal of Indian monsoon, which alters the flow regime across Bab El Mandab [7,8], playing an important role in the stratification and circulation of the Gulf of Aden [9]. Hydrography of the Gulf of Aden and Arabian Sea is significantly influenced by seasonal changes during the SW monsoon-associated rainfall. During SW monsoon (June-September), wind-driven upwelling occurs in the study area, which brings cool, nutrient-enriched subsurface water to the surface, enhancing the phytoplankton production [10]. During the NE monsoon (December-February), NE winds blow over the region bringing significantly low rainfall in the study domain compared to the SW monsoon and leading to low phytoplankton production. The Yemen coast region is characterized by a narrow coastal plain between the Gulf of Aden and the mountain range that parallels the shoreline. It is influenced by two distinct monsoon seasons as global pressure patterns re-adjust to the changing incoming solar energy $[11,12]$. The climate of the Yemen coast and nearby waters is dominated by hot and extremely arid conditions characteristics of North Africa and penins [13,14]. The area of the Gulf of Aden and Arabian Sea water needs intensive hydrographical study. Consequently, the present work was carried out to study and understand the spatial distribution of hydrographical properties to identify the role of water circulation governing their distribution in the coastal area of the Gulf of Aden and Arabian Sea in August 2014 and January 2015. This study could serve as a baseline upon which changes in the hydrographical properties of coastal waters of the Gulf of Aden and Arabian Sea could be explored using more recent and or future data sets.

\section{Description of the Study Area}

The Gulf of Aden situated in the NW Arabian Sea and connected to the Red Sea through the Strait of Bab Bab El Mandab and is opened at its easterly end to the Arabian Sea through a wider and deeper mouth [7]. It is a narrow, elongated, oceanic basin bordering the coastlines of southern Yemen and northern Somalia (Figure 1). The Gulf of Aden is about $900 \mathrm{~km}$ in length, with an average depth of approximately $1800 \mathrm{~m}$, and has a total area of $\sim 220,000 \mathrm{~km}^{2}$ [15]. On its western side, the strait of Bab El Mandab permits water exchange between the Gulf of Aden and the Red Sea, whereas the eastern end of the gulf opens to the NW Arabian Sea [16]. The Gulf of Aden is characterised by high levels of marine biodiversity and provides an essential resource to its neighbouring countries and is an important provider of food to coastal populations [17]. It is an important commercial shipping route for international trade, particularly petroleum. A substantial $12 \%$ of the world's oil supply is transported through the Gulf of Aden by $\sim 50,000$ vessels each year [18]. The area is subjected to reversing monsoons. During the NE monsoon (October to May) the prevailing wind over the Arabian Sea is northeasterly veering to easterly in the Gulf of Aden and southeasterly towards the Strait of Bab El Mandab and Southern Red Sea. The stronger winds during the SW monsoon (JuneSeptember) are from WSW over the Gulf of Aden and Arabian Sea 
and from NW over the Southern Red Sea [19]. The climate of the Gulf of Aden and Arabian Sea is dominated by hot, extremely arid conditions. The area is subjected to the Indian Ocean monsoon system (Figure 2).
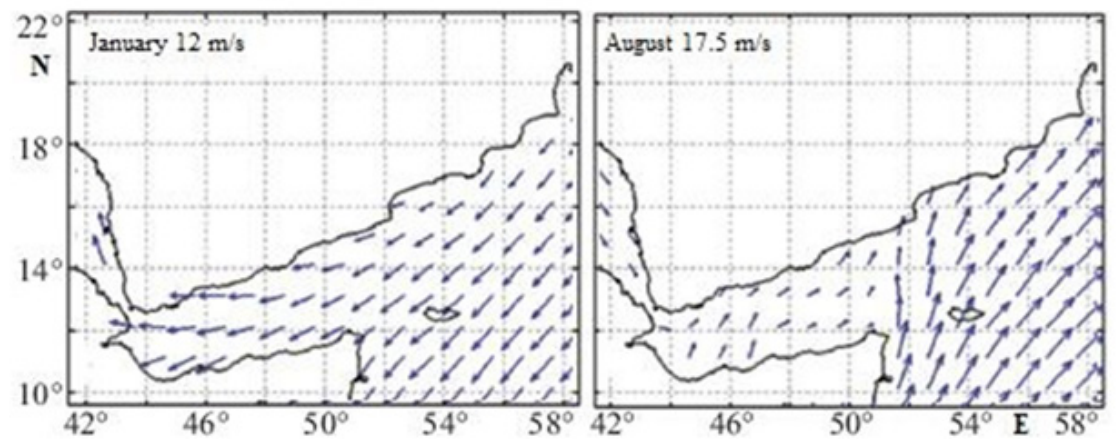

Figure 2: Gulf of Aden and Arabian Sea climatological QuikSCAT wind speed (m/s) for January and August, NE and SW monsoon [16,20].

From January to March the NE monsoon blows in a south western direction. Between May and September, the SW monsoon generates winds in a blow offshore and replaced by cooler nutrient rich water from deeper layers. This upwelling's limited the growth of coral reefs, but they trigger high primary production which supports the regions rich pelagic fish stocks $[19,21,22]$.

\section{Material and Methods}

The study area situated in the coastal surface seawater on the Gulf of Aden and Arabian Sea coast of Yemen. Twelve stations near to the Yemeni coast were selected to cover the study area. The positions of the sampling stations were accurately located by using a hand held Global Positioning System (GPS). For generalizing the hydrographical conditions with more clarity, the sampling periods were classified into two periods; 11-16 August 2014 (SW monsoon) and 11-16 January 2015 (NE monsoon). The hydrographic properties including temperature, $\mathrm{pH}$, salinity, DO and total alkalinity. Air and water temperature were measured at the time of sampling, using standard reversing protected thermometers, with accuracy of $0.01^{\circ} \mathrm{C}$. The sea water samples were collected at $1 \mathrm{~m}$ below the water surface through a water sampler and transferred in dark polyethylene bottles and kept in dark box for $\mathrm{pH}$, salinity, DO and total alkalinity determination in the laboratory. The combination electrode was standardized with pH. 400 and pH 7.00 buffers at $25^{\circ} \mathrm{C}$. The $\mathrm{pH}$ was calculated from:

$$
p H_{s w}=\left(E_{s w}-E_{4}\right) / S
$$

Where $\mathrm{pH}_{\mathrm{sw}}$ is the $\mathrm{pH}$ of the ample, $\mathrm{E}_{\mathrm{sw}}$ and $\mathrm{E}_{4}$ are the measured potential of the sample and 4.0 buffer, respectively, and $\mathrm{S}$ is the measured slope of the electrodes obtained from:

$$
S=\left(E_{4}-E_{7}\right) /(4.00-7.00)
$$

Where $E_{7}$ is the measured potential of the buffer solution 7.00. The slope of the electrode response was constant over long periods, and measurements of 7.00 buffer were made of the beginning and the end of the day. Salinity was estimated against Copenhagen Standard Seawater. DO was estimated by the modified Winkler's titramation method $[23,24]$. Total alkalinity was determined by the method of Anderson and Robinson [25] as developed by Culberson [26]. All measurements of $\mathrm{pH}$ and total alkalinity were made at $25 \pm 0.1^{\circ} \mathrm{C}$, where the samples were placed in water bath for $10-20$ minutes before measurements. The $\mathrm{pH}$-meter used was digital $\mathrm{pH} /$ $\mathrm{mV}$ meter. The precision of the measurements were \pm 0.01 for $\mathrm{pH}$ and $\pm 0.009 \mathrm{meq} / \mathrm{l}$ for alkalinity. The results were calculated as the mean value of the triplicate tests. The correlation matrix (Pearson's correlation coefficients) was carried out by Excel software.

\section{Results and Discussion}

Table 1: Mean concentration of hydrographic properties at selected stations in the Gulf of Aden and Arabian Sea coast surface water during August

\begin{tabular}{|c|c|c|c|c|c|c|c|c|}
\hline Station No. & Location Name & Month & $\begin{array}{c}\text { Air Temperature } \\
\left({ }^{\circ} \mathrm{C}\right)\end{array}$ & $\begin{array}{l}\text { Water } \\
\text { Tempera- } \\
\text { ture }\left({ }^{\circ} \mathrm{c}\right)\end{array}$ & Salinity (\%o) & $\begin{array}{c}\text { Dissolved } \\
\text { Oxygen } \\
\text { (mg/l) }\end{array}$ & pH & $\begin{array}{l}\text { Total Alkalinity } \\
\text { (meq/l) }\end{array}$ \\
\hline \multirow{2}{*}{1} & \multirow{2}{*}{ As suqayyah } & Aug. 2014 & 26.3 & 28 & 36.5 & 4.65 & 7.9 & 2.325 \\
\hline & & Jan. 2015 & 25.8 & 28.3 & 36.8 & 4.8 & 8.02 & 2.33 \\
\hline \multirow{2}{*}{2} & \multirow{2}{*}{ Khor-Omair } & Aug. 2014 & 26.1 & 28.1 & 36.3 & 4.63 & 7.95 & 2.323 \\
\hline & & Jan. 2015 & 26 & 28.7 & 36.7 & 4.78 & 8.01 & 2.294 \\
\hline \multirow{2}{*}{3} & \multirow{2}{*}{ Aden } & Aug. 2014 & 25.3 & 27.9 & 36.2 & 4.6 & 7.99 & 2.32 \\
\hline & & Jan. 2015 & 25.5 & 27.3 & 36.5 & 4.81 & 8 & 2.308 \\
\hline
\end{tabular}
2014 and January 2015. 


\begin{tabular}{|c|c|c|c|c|c|c|c|c|}
\hline \multirow{2}{*}{4} & \multirow{2}{*}{ Shuqrah } & Aug. 2014 & 25.1 & 27 & 36.3 & 4.58 & 8 & 2.315 \\
\hline & & Jan. 2015 & 26.3 & 27.1 & 36.3 & 4.93 & 8.01 & 2.29 \\
\hline \multirow{2}{*}{5} & \multirow{2}{*}{ Ahwar } & Aug. 2014 & 24.3 & 26.9 & 36.2 & 4.5 & 8.01 & 2.319 \\
\hline & & Jan. 2015 & 24.8 & 27.2 & 36.4 & 4.9 & 7.95 & 2.234 \\
\hline \multirow{2}{*}{6} & \multirow{2}{*}{ Balhaf } & Aug. 2014 & 23.8 & 26 & 36.1 & 4.5 & 8 & 2.316 \\
\hline & & Jan. 2015 & 24.3 & 26.7 & 36.2 & 4.95 & 8.02 & 2.328 \\
\hline \multirow{2}{*}{7} & \multirow{2}{*}{ Al-Mukalla } & Aug. 2014 & 22.6 & 25.9 & 36 & 4.48 & 7.93 & 2.28 \\
\hline & & Jan. 2015 & 24.6 & 26.3 & 36.1 & 4.94 & 7.89 & 2.28 \\
\hline \multirow{2}{*}{8} & \multirow{2}{*}{ Qusayír } & Aug. 2014 & 22.3 & 25.3 & 35 & 4.3 & 8.02 & 2.313 \\
\hline & & Jan. 2015 & 23.8 & 26.1 & 36.2 & 4.99 & 8.03 & 2.288 \\
\hline \multirow{2}{*}{9} & \multirow{2}{*}{ Ras Sharwin } & Aug. 2014 & 22.1 & 25.1 & 35.7 & 4.27 & 8.01 & 2.317 \\
\hline & & Jan. 2015 & 23.1 & 25.9 & 35.9 & 5.3 & 8.01 & 2.359 \\
\hline \multirow{2}{*}{10} & \multirow{2}{*}{ Haswayn } & Aug. 2014 & 22 & 24.3 & 35.6 & 4.3 & 8 & 2.313 \\
\hline & & Jan. 2015 & 23 & 25.7 & 35.8 & 5.4 & 8.03 & 2.301 \\
\hline \multirow{2}{*}{11} & \multirow{2}{*}{ Al-Muhyfif } & Aug. 2014 & 22.9 & 24.1 & 35.3 & 4.15 & 7.9 & 2.273 \\
\hline & & Jan. 2015 & 23.1 & 25.3 & 35.6 & 5.3 & 8.02 & 2.3 \\
\hline \multirow{2}{*}{12} & \multirow{2}{*}{ Hawf } & Aug. 2014 & 22.8 & 23.7 & 35 & 4.1 & 7.88 & 2.27 \\
\hline & & Jan. 2015 & 23 & 25.2 & 35.3 & 5.5 & 8.03 & 2.303 \\
\hline \multirow{2}{*}{\multicolumn{2}{|c|}{ Minimum }} & Aug. 2014 & 22 & 23.7 & 35 & 4.1 & 7.88 & 2.27 \\
\hline & & Jan. 2015 & 23 & 25.2 & 35.3 & 4.78 & 7.89 & 2.234 \\
\hline \multirow{2}{*}{\multicolumn{2}{|c|}{ Maximum }} & Aug. 2014 & 26.3 & 28.1 & 36.5 & 4.65 & 8.02 & 2.325 \\
\hline & & Jan. 2015 & 26.3 & 28.7 & 36.8 & 5.5 & 8.03 & 2.359 \\
\hline \multirow{2}{*}{\multicolumn{2}{|c|}{ Average }} & Aug. 2014 & 23.8 & 26.03 & 35.85 & 4.42 & 7.97 & 2.307 \\
\hline & & Jan. 2015 & 24.44 & 26.65 & 36.15 & 5.05 & 8 & 2.301 \\
\hline \multirow{2}{*}{\multicolumn{2}{|c|}{ Standard deviation }} & Aug. 2014 & 1.58 & 1.56 & 0.52 & 0.19 & 0.05 & 0.02 \\
\hline & & Jan. 2015 & 1.25 & 1.11 & 0.44 & 0.25 & 0.04 & 0.031 \\
\hline \multirow{2}{*}{\multicolumn{2}{|c|}{ Cofficient of variation }} & Aug. 2014 & 6.63 & 6.01 & 1.45 & 4.3 & 0.64 & 0.873 \\
\hline & & Jan. 2015 & 5.11 & 4.18 & 1.22 & 5.02 & 0.52 & 1.327 \\
\hline
\end{tabular}
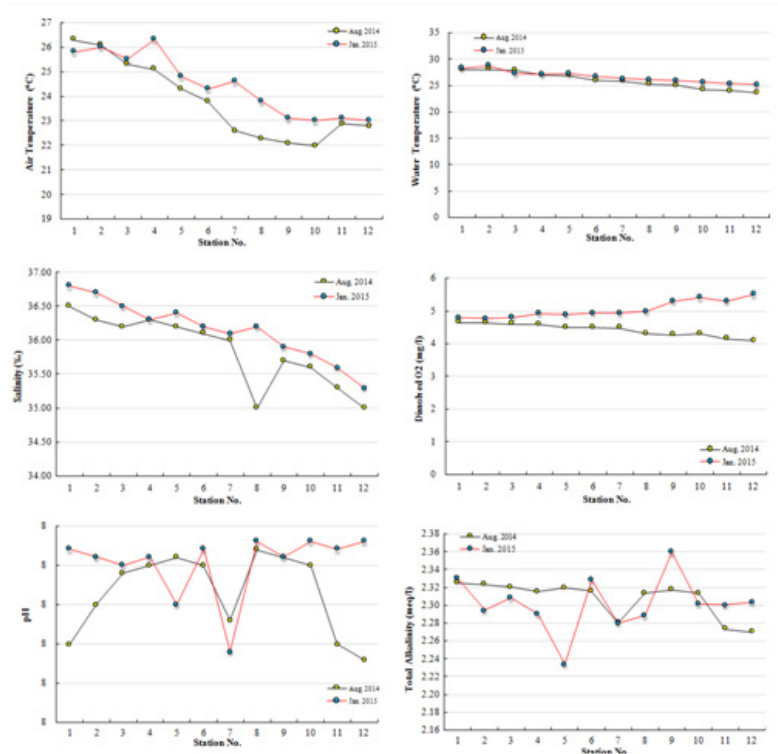

Figure 3: Spatial distribution of air and water temperature, salinity, dissloved oxygen, $\mathrm{pH}$ and total alkalinity at selected stations in the Gulf of Aden and Arabian Sea coast surface water during August 2014 and January 2015. 
Hydrographical properties of surface sea water were determined according to standard methods. The common hydrographical properties of water like temperature, $\mathrm{pH}$, salinity, DO and total alkalinity have been determined. The significant variation in hydrographical properties along these stations is shown in (Table 1 and Figure 3).

\section{Temperature}

The temperature was basically important for its effects on the chemistry and biological activities of organisms in water. Temperature was known to influence in the determination of other factors like $\mathrm{pH}$, dissolved gases and alkalinity. Generally, the surface water temperature is influenced by the intensity of solar radiation, evaporation, freshwater influx and cooling and mix up with ebb tide and the water flow from adjoining neritic zone waters [27] The normal range to which fish is adapted in the tropics is between $8^{\circ} \mathrm{C}$ and $30^{\circ} \mathrm{C}$ [28]. In August 2014, the water temperature ranged between $23.70^{\circ} \mathrm{C}$ at station 12 and $28.10^{\circ} \mathrm{C}$ at station 2 with mean value of $26.03 \pm 1.56^{\circ} \mathrm{C}$, while it ranged between $25.20^{\circ} \mathrm{C}$ at station 12 and $28.70{ }^{\circ} \mathrm{C}$ at station 2 with mean value of $26.65 \pm 1.11{ }^{\circ} \mathrm{C}$ in January 2015. The air temperature ranged between $22.00{ }^{\circ} \mathrm{C}$ at station 10 and $26.30^{\circ} \mathrm{C}$ at station 1 with mean value of $23.80 \pm 1.58^{\circ} \mathrm{C}$ in August 2014, while it ranged between $23.00^{\circ} \mathrm{C}$ at station 12 and $26.30 \mathrm{oC}$ at station 4 with mean value of $24.44 \pm 1.25{ }^{\circ} \mathrm{C}$ in January 2015. Such distribution reflects that the inshore surface waters are caused by upwelling current off somalia. The difference between the air temperature due to a strong decrease in mean surface temperature in the eastern Gulf of Aden during these months, the result of upwelling current off Somalia [11]. There were variations in air and surface sea water temperatures across all the stations, however, these variations were not significantly different across the stations.

\section{Hydrogen Ion concentration (pH)}

$\mathrm{pH}$ as one of the vital environmental characteristics decides the survival, metabolism, physiology and growth of aquatic organisms pH may be affected by total alkalinity and acidity, run off from surrounding areas and water discharges [29]. The surface spatial horizontal distribution of $\mathrm{pH}$ in the study area is shown in (Table 1 and Figure 3). The $\mathrm{pH}$ changes in the water are governed by the amount of free $\mathrm{CO}_{2}$, carbonates, bicarbonate and hydroxyl ion. These changes are accompanied by the changes in other hydrographic properties that in turn influence the quality of water. Almost neutral $\mathrm{pH}$ is observed in all the locations throughout the sampling events. According to Umavathi et al. [30] pH range between 5 and 8.5 is best for plankton growth. Boyd and Lichtkoppler [31] reported $\mathrm{pH}$ range of 6.09-8.45 as being ideal for supporting aquatic life including fish. In this study the $\mathrm{pH}$ values ranged between 7.88 at station 12 and 8.02 at station 8 with mean value of $7.97 \pm 0.05$ in August 2014, while it ranged between 7.89 at station 7 and 8.03 at stations 10 and 12 with mean value of $8.00 \pm 0.04$ in January 2015 (Table 1 and Figure 3). These variations were not significantly different across the stations. The results show that the water from all stations were moderately alkaline ( $\mathrm{pH} 7.88-8.03$ ) and within the permissible limit ( $\mathrm{pH}$ 6-8.5) for aquatic life like fish and plankton growth. The low $\mathrm{pH}$ is due to the dilution of seawater by fresh water flow and runoff during the monsoon season [32]. Generally, fluctuations in $\mathrm{pH}$ values during different seasons of the year is attributed to factors like removal of $\mathrm{CO}_{2}$ by photosynthesis through bicarbonate degradation, dilution of seawater by freshwater influx, reduction of temperature and salinity and decomposition of organic matter [33,34]. The recorded high $\mathrm{pH}$ values during january 2015 might be due to the influence of seawater penetration and high biological activity like photosynthesis by dense phytoplankton blooms. The general pattern of the surface horizontal distribution of $\mathrm{pH}$ gave local variation mainly due to the climate conditions, and consequently water temperature, DO content and biological activity $[35,36]$.

\section{Salinity}

Salinity is an important water quality property monitored by freshwater and marine ecologists because of its influence on the biota. Most aquatic organisms are adapted to only a narrow range of salinity, beyond which they cannot maintain their osmotic and ionic balance. Some species tolerate only intermediate levels of salinity while broadly adopted species can acclimate to variable salinity ranging from fresh water to seawater. Less wave and tidal action with decreased freshwater inflow and land drainage may be considered fluctuations in salinity [37]. The changes in the salinity in the coastal waters are due to the influx of freshwater inflow from land runoff caused by monsoon, or by tidal variations. In this study, salinity ranged between $35.00 \%$ at station 12 and $36.50 \%$ at station 1 with an average value of $35.85 \pm 0.52 \%$ in August 2014, while it ranged between $35.30 \%$ at station 12 and $36.80 \%$ at station 1 with an average value of $36.15 \pm 0.44 \%$ in January 2015 (Table 1 and Figure 3). Higher values in January 2015 could be attributed to high degree of evaporation with decreased freshwater inflow and land drainage. Lower values in salinity during August 2014 may be related to heavy showers and consecutive floodwater from up lands. The subsurface warm and high saline outflow from the Red Sea into the Gulf of Aden is distinctly seasonal. It increases during winter (October to May) and attenuated or blocked in summer (July- August) [7, 38-43]. In January, the salinity at the surface levels generally increases towards the station 1 in the west. The salinity in the surface layer in the western part of the Gulf is generally lower than that in August due to the monsoonal reversal of surface current. In the western Gulf of Aden, salinity is relatively higher than the eastern part of Arabian Sea. This conclusion is agreement with published literature [19]. In the Gulf of Aden, the winter northeasterly winds cause surface water to move towards Bab El Mandab, particularly against the Arabian coast. During the August, the stronger winds of the SW monsoon cause the surface water to move out of the Gulf of Aden towards the Arabian Sea and an anticyclonic gyre is developed in the central part of the 
Gulf of Aden [44]. The strong winds of the SW monsoon during July-September also cause an intensive seasonal upwelling over a very wide area off Southern Arabia [44-48]. The salinity readings were not more difference. These variations may be mainly due to local hydrographic condition such as semi-isolated, intensive evaporation and restricted circulation [49]. The surface seawater in the Gulf of Aden and Arabian Sea is considered as a mixture of high salinity southern Red Sea surface water driven into the Gulf of Aden during August; relatively low salinity surface water from the Arabian Sea entering the Gulf of Aden during January and upwelled water in the Gulf of Aden during August, which are characterized by low temperature, low salinity and low oxygen content.

\section{Dissolved oxygen (DO)}

The DO is very essential for the respiratory metabolism of all aquatic animals. It favors the stability and availability of nutrients to the animals. Therefore, it increases the productivity of the ecosystems. Usually the DO content in the water samples depends on the temperature and seasons. In marine environments, DO is a result of physical and biological processes; DO distribution is determined by the interplay of physical (atmospheric exchange and mixing) and biological (photosynthetic production and respiration) processes [50]. Numerous scientific studies suggest that 4-9 mg/l of DO is the optimal range that will support a large, diverse fish population [51]. In general, concentrations of DO above $5 \mathrm{mg} / \mathrm{l}$ are considered supportive of marine life, while concentrations below this are potentially harmful. At about $3 \mathrm{mg} / \mathrm{l}$, bottom fishes may start to leave the area, and the growth of sensitive species such as crab larvae is reduced. At $2.5 \mathrm{mg} / \mathrm{l}$, the larvae of less sensitive species of crustaceans may start to die, and the growth of crab species is more severely limited. Below $2 \mathrm{mg} / \mathrm{l}$, some juvenile fish and crustaceans that cannot leave the area may die, and below $1 \mathrm{mg} / \mathrm{l}$, fish totally avoid the area or begin to die in large numbers [52]. In the study area, the DO ranged from $4.10 \mathrm{mg} / \mathrm{l}$ at station 12 and $4.65 \mathrm{mg} / \mathrm{l}$ at station 1 with mean value of $4.42 \pm 0.19 \mathrm{mg} / \mathrm{l}$ in August 2014, while it ranged from $4.78 \mathrm{mg} / \mathrm{l}$ at station 2 to $5.50 \mathrm{mg} / \mathrm{l}$ at station 12 with an average value of $5.05 \pm 0.25$ in January 2015 (Table 1 and Figure 3 ). These fluctuations may be attributed to several hydrographic and biological condition prevails at various locations. The DO shows very strong positive correlation with temperature and salinity in August 2014, while it shows very stronge negative correlation with temperature and salinity in January 2015 (Table 2).

Table 2: Correlation coefficient values between the hydrographical properties at selected stations in the Gulf of Aden and Arabian Sea coast surface water.

\begin{tabular}{|c|c|c|c|c|c|c|}
\hline & Air temp. & Water temp. & Salinity & DO & pH & Total alkalinity \\
\hline \multirow{2}{*}{ Air temp. } & 1 & & & & & \\
\hline & 0.89 & & & & & \\
\hline Water temp. & $0.90 *$ & 1 & & & & \\
\hline \multirow{2}{*}{ Salinity } & 0.78 & 0.87 & \multirow{2}{*}{1} & & & \\
\hline & $0.86^{*}$ & $0.94 *$ & & & & \\
\hline \multirow{2}{*}{ DO } & 0.82 & 0.96 & 0.93 & \multirow{2}{*}{1} & & \\
\hline & $-0.88^{*}$ & $-0.87^{*}$ & $-0.94 *$ & & & \\
\hline \multirow{2}{*}{$\mathrm{pH}$} & -0.15 & 0.17 & 0.14 & 0.22 & \multirow{2}{*}{1} & \\
\hline & $-0.22^{*}$ & $-0.10^{*}$ & $-0.17^{*}$ & $0.33^{*}$ & & \\
\hline \multirow{2}{*}{ Total alkalinity } & 0.52 & 0.7 & 0.62 & 0.69 & 0.65 & \multirow{2}{*}{1} \\
\hline & $-0.21 *$ & $-0.09 *$ & $-0.10^{*}$ & $0.23^{*}$ & $0.49 *$ & \\
\hline
\end{tabular}

$r=0.89$ for August 2014

$r=0.90 *$ for January 2015

Bold emphasis indicate the significant positive and negative correlations

DO concentrations in surface waters are lower in summer than winter due to higher temperatures and salinity [53]. The surface water of the Gulf of Aden and Arabian Sea along the coast of Yemen contained sufficient amount of DO and many aquatic animals and aquatic insects can survive.

\section{Total alkalinity}

The total alkalinity value varies from $2.270 \mathrm{meq} / \mathrm{l}$ at station 12 to $2.325 \mathrm{meq} / \mathrm{l}$ at station 1 with the mean value of $2.307 \pm 0.020$ meq/l in Auguast 2014, while the total alkalinity value varies from $2.234 \mathrm{meq} / \mathrm{l}$ at station 5 to 2.359 at station 9 with the mean value of $2.301 \pm 0.031 \mathrm{meq} / \mathrm{l}$ in January 2015 (Table 1 and Figure 3). These values of total alkalinity are possibly caused by the mixing processes and temperature increase which both expel $\mathrm{CO}_{2}$ and photosynthesis processes. The photosynthesis processes is confirmed by the high values of $\mathrm{O}_{2}$ content of surface seawater [54].

\section{Conclusion}

In this study, the water quality properties in terms of its hydrographical properties of the Gulf of Aden and Arabian Sea coast water of Yemen were assessed. The values obtained for the air and water temperature, $\mathrm{pH}$, salinity, $\mathrm{DO}$ and total alkalinity were within the recommended values of the World Health Organization (WHO) and United State Environmental Protection Agency (USEPA) 
for survival, metabolism and physiology of aquatic organisms. The difference between the values may be mainly due to local hydrographical condition such as semi-closed ports; semi-isolated shores; intensive evaporation and several biological conditions prevailed at various locations.

\section{Acknowledgement}

None.

\section{Conflict of Interest}

No Conflict of interest.

\section{References}

1. Rai SV, Rajashekhar M (2014) Seasonal Assessment of Hydrographic Variables and Phytoplankton Community in the Arabian Sea Waters of Kerala, Southwest Coast of India. Brazilian Journal of Oceanography 62(4): 279-293.

2. Lawson EO (2011) Physico-chemical parameters and heavy metal contents of water from the Mangrove swamps of Lagos Lagoon, Lagos, Nigeria. Advances in Biological Research 5(1): 8-21.

3. Damotharan P, VengadehPerumal N, Arumugam M, Vijayalakshmi S, Balasubramnian T (2010) Seasonal variation of physicochemical characteristics in point Calimere coastal waters (South East Coast of India). Middle-East Journal of Scientific Research 6(4): 333-339.

4. Poonam B, Rahul K (2012). Status of seawater quality at few industrially important coasts of Gujarat (India) off Arabian Sea. Indian Journal of Geo-Marine Sciences 41(1): 90-97.

5. Chakrapani GJ, Subramanian V (1993) Rate of Erosion and Sedimentation in the Mahanadi River Basin. India Journal of Hydrology 149(4): 39-48.

6. Thirupathaiah M, Samatha CH, Sammaiah C (2012) Analysis of water quality using physico-chemical parameters in lower Manair reservoir of Karimnagar district, Andhra Pradesh. International Journal of Environmental Sciences 3(1): 172-180.

7. Murray SP, Johns W (1997) Direct observations of seasonal exchange through the Bab el Mandab Strait. Geophysical Research Letters 24: $2557-2560$.

8. Smeed D (1997) Seasonal variation of the flow in the strait of Bab al Mandab. Oceanol Acta 20(6): 773-781

9. Johns WE, Sofianos SS (2012) Atmospherically forced exchange through the Bab el Mandeb Strait. J Phys Oceanogr 42 (7): 1143-1157. 8 of 8

10. Jyothibabu R, Ashadevi CR, Madhu NV, Sabu P, Jayalakshmy KV (2008) The response of microzooplankton $(20-200 \mu \mathrm{m})$ to coastal upwelling and summer stratification in the southeastern Arabian Sea. Cont Shelf Res 28: 653-671.

11. Naval Oceanography Command Detachment (1982) Climate study of the near coastal zone Red Sea South and Gulf of Aden. U.S. Naval Oceanographic command Detachment Asheville NC.

12. Aden Port Development (1996) Phase I reports. The Marking Department. Port of Aden Aden Yemen.

13. Goldegrg ED (1975) The Health of the Oceans. UNESCO Press Paris.

14. PERSGA (1995) Regional program of action for protection of the marine environment of the Red Sea and Gulf of Aden from land-base sources pollution. p. 30

15. Al Saafani MA, Shenoi SSC, Shankar D, Aparna M, Kurian J, et al. (2007) Westward movement of eddies into the Gulf of Aden from the Arabian Sea. J Geophys Res 112: C11004

16. Gittings JA, Raitsos DE, Racault M, Brewin RJ, Pradhan Y, et al. (2017) Seasonal phytoplankton blooms in the Gulf of Aden revealed by remote sensing. Remote Sensing of Environment 189: 56-66.
17. Gladstone W, Tawfiq N, Nasr D, Andersen I, Cheung C, et al. (1999) Sustainable use of renewable resources and conservation in the Red Sea and Gulf of Aden: issues, needs and strategic actions. Ocean Coast Manag 42: 671-697.

18. Kraska J, Wilson B (2009) Piracy repression, partnering and the law. J Marit Law Commer 40.

19. Morcos S, AbdAllah AM (2012) Oceanography of the Gulf of Aden, John Murray-Mabahiss Expedition 1933-1934 Revisited. Egyptian Journal of Aquatic Research 38: 77-91.

20. Alkawri A, Gamoyo M (2014) Remote sensing of phytoplankton distribution in the Red Sea and Gulf of Aden. Acta Oceanol Sinica 33 (9): 93-99.

21. Alsayed A, Ghaddaf M (1993) Upwelling and Fish mortality in the northern Gulf of Aden. Indian Journal of Marine Sciences 22: 305-307.

22. UNDP/GEF (1996) Biodiversity Conservation and Sustainable Development programme. Socotra Archipelago, Republic of Yemen. Mac Alister Elliott and partners Ltd United Kingdom.

23. Strickland JDH, Parsons TRA (1972) Practical Handbook of Seawater Analysis.2nd ed. Fisheries Research Board of Canada Ottawa p. 310.

24. Grasshoff K, Ehrharrot M, Kremling K (1983) Methods for seawater analysis. 2nd Edition Verlag Chemic Weinheim p. 419.

25. Anderson DH, Robinson RJ (1964) Rapid electrometric determination of the alkalinity of sea water using a glass electrode. Ind Eng Chem Analyst Edit 18: 767-769.

26. Culberson C (1970) Seawater alkalinity determination by the method. J Mar Res 28(1): 15-21.

27. Govindasamy C, Kannan L, Jayapaul A (2000) Seasonal variation in physico-chemical properties and primary production in the coastal water biotopes of Coromandel coast, India. J Environ Biol 21: 1-7.

28. Alabaster JS, Lloyd R (1980) Water quality criteria for fresh water fish. 2nd edition, p.325.

29. Velsamy G, Manoharan N, Ganesan S (2013) Analysis of PhysicoChemical Variations in Sea Water samples Uppanar Estuary, Cuddalore, Tamilnadu, India. International Journal of Research in Biological Sciences 3(2): 80-83.

30. Umavathi S, Longakumar K, Subhashini (2007) Studies on the nutrient content of Sulur pond in Coimbator, Tamil Nadu. Journal of Ecology and Environmental Conservation 13(5): 501-504.

31. Boyd CE, Lichtkoppler FR (1979) Water quality management in pond fish culture. Research and Development Series 22- 30.

32. Subramanian B, Mahadevan A (1999) Seasonal and diurnal variation of hydrobiological characters of coastal waters of Chennai, Bay of Bengal. Indian J Mar Sci 28: 429-433.

33. Upadhyay S (1988) Physico-chemical characteristics of the Mahanadi estuarine ecosystem, east coast of India. Ind J Mar Sci 17:19-23.

34. Rajasegar M (2003) Physico-chemical characteristics of the Vellar estuary in relation to shrimp farming. J Environ Biol 24(1): 95-101.

35. Hann RGM, Saad MAH, Kandeel MM (1988) Hydrographical studies on the Red Sea water in front of Hurgada. Marine Mesopotanic 2: 139-156.

36. Al-Shwafi NA (2009) Hydrographical studies in seawater from Yemeni ports. University Aden Journal for applied Sciences 13(1).

37. Sampathkumar P, Kannan L (1998) Seasonal variations in physicochemical characteristics in the Tranquebar- Nagapattinam region, southeast coast of India. Poll Res 17(4): 397-402.

38. Patzert WC (1974) Wind-induced reversal in the Red Sea circulation. Deep-Sea Research 21: 109-121.

39. Osman MM (1985) Water exchange between the Red Sea and Gulf of Aden. International Symposium Upwelling W Africa Inst Invest PESQ Barcelona 1: 205-212. 
40. Maillard C, Soliman G (1986) Hydrography of the Red Sea and exchanges with the Indian Ocean in summer. Oceanologica Acta 9(3): 249-269.

41. Bower AS, Hunt HD, Price JF (2000) Character and dynamics of the Red Sea and Persian Gulf outflows. Journal of Geophysical Research 105(3): 6387-6414.

42. Beal LM, Ffield A, Gordon AL (2000) Spreading of Red Sea overflow waters in the Indian Ocean. Journal of Geophysical Research 105(4): 8549-8564.

43. Peters H, Johns WE, Bower AS, Fratantoni DM (2005) Mixing and Entrainment in the Red Sea outflow plume. Part I: Plume structure. Journal of Physical Oceanography 35: 569-583.

44. Stirn J, Edwards R, Piechura J, Savich M, Ghaddaf M (1985) Oceanographic conditions, pelagic productivity, and living resources in the Gulf of Aden. IOC/UNESCO Workshop Report 37: 255-297.

45. Bogdanova AK (1966) Hydrological characteristics of the Red Sea and the Gulf of Aden according to the observations of the research vessel Academic Kovalevsky. Okeanol Isled 15: 45-68.

46. Smith RL (1968) Upwelling. In: Barnes, H (Ed.), Oceanography and Marine Biology, Annual Review, George Allen and Unwin, London, 6:1146.

47. Swallow JC (1984) Some aspects of the physical oceanography of the Indian Ocean. Deep-Sea Research Part A 31 (6- 8A): 639-650.
48. AbdAllah AM (2001) Oceanographic conditions off the Southern Coast of Yemen during South-West Monsoon. Bulletin of the Faculty of Science University of Alexandria Egypt 41 (1-2): 33-45.

49. Al-Shwafi NA, (2001) Beach tar along the Red Sea coast of Yemen "Quantitative Estimation and Qualitative Determination". Ph. D Thesis Dept. Earth and Environmental Science Faculty of Science Sana'a University p.186.

50. Hussein M, Courp T, Ibrahim A, Benkhelil J (2011) Seasonal variability of hydrographical properties of the Syrian marine water. Journal of Marine Systems 85: 30-44.

51. Abdus-Salam N, Adekola FA, Apata AO (2010) A Physico-chemical Assessment of Water quality of oil producing areas of Ilaje, Nigeria. Advances in Natural and Applied Sciences 4(3): 333-344.

52. United State Environmental Protection Agency (USEPA) (2000) Ambient aquatic life water quality criteria for Dissolved Oxygen (saltwater), Cape Cod to Cape Hatteras. EPA/822/R-00/12.

53. Poisson A, Morcos S, Souvermezoglou E, Papaud A, Ivanoff A (1984) Some aspects of biochemical cycles in the Red Sea with special reference to new observations made in summer 1982. Deep-Sea Research A31: 707-718.

54. Rushdi AI (1994) pH and alkalinity of Yemen coast during wintertime: Red Sea. 